\title{
Commentary: May the force be with you
}

\author{
Tomasz A. Timek, MD, PhD
}

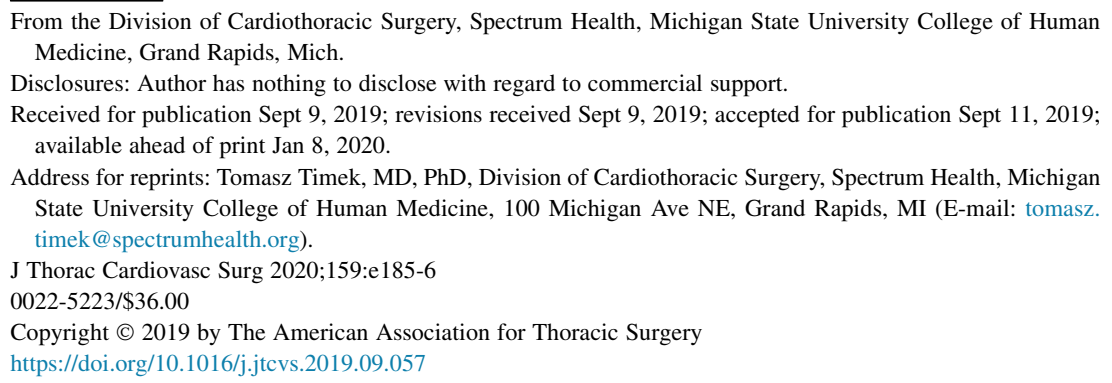

From the Division of Cardiothoracic Surgery, Spectrum Health, Michigan State University College of Human Medicine, Grand Rapids, Mich.

Disclosures: Author has nothing to disclose with regard to commercial support.

Received for publication Sept 9, 2019; revisions received Sept 9, 2019; accepted for publication Sept 11, 2019; available ahead of print Jan 8, 2020.

Address for reprints: Tomasz Timek, MD, PhD, Division of Cardiothoracic Surgery, Spectrum Health, Michigan State University College of Human Medicine, 100 Michigan Ave NE, Grand Rapids, MI (E-mail: tomasz. timek@spectrumhealth.org).

J Thorac Cardiovasc Surg 2020;159:e185-6

$0022-5223 / \$ 36.00$

Copyright (C) 2019 by The American Association for Thoracic Surgery

https://doi.org/10.1016/j.jtcvs.2019.09.057

Technologic advances have been at the core of our specialty, from invention of the first cardiopulmonary bypass machine that made it all possible ${ }^{1}$ to current transcatheter valve therapies that are transforming the field. ${ }^{2}$ Biologic sensors have successfully been used to monitor rhythm disturbances ${ }^{3}$ and myocardial function, ${ }^{4}$ and in the current issue of the Journal, Grinberg and colleagues ${ }^{5}$ introduce an innovative piezoresistive pressure sensor to evaluate mitral valve coaptation forces after repair. The device is a thin sheet of flexible polyamide, which is lined with miniature pressure sensors made from resistive ink. The apparatus is inserted between the mitral leaflets to yield an in vivo pressure map of leaflet coaptation across the line of valve closure after weaning from cardiopulmonary bypass. Although it is still in early stages of development, the device carries the hope of improving predictability and durability of mitral valve repair beyond the static intraoperative tests used today.

Competent mitral valve closure, although intuitively simple, requires coordinated and timely integration of atrial, annular, and subvalvular components of the mitral complex with hemodynamic facilitation. Ovine studies ${ }^{6}$ have shown that majority of mitral valve closure occurs before ventricular systole, and leaflet coaptation is complete only 30 milliseconds after end-diastole, when ventricular pressure is still relatively low. During normal valve closure, the pressure rise during ventricular systole thus acts to seal rather than close the valve, which is prepositioned in late diastole. In this context, it is unclear whether greater apposition forces between the leaflets reflect optimal or improved valve closure. Furthermore, these dynamics are dependent on normal annular motion and atrioventricular synchrony. The rings universally used annular in mitral valve repair, however, essentially abolish normal annular dyanmics ${ }^{7}$ and freeze the motion of the posterior mitral leaflet. ${ }^{8}$ These prostheses have also been demonstrated to alter anterior leaflet strain $^{9}$ and dimensions ${ }^{10}$ in vivo. The anterior mitral leaflet also embodies an intrinsic contractile system ${ }^{11}$ that may alter its stiffness through parasympathetic stimulation; however, resective reparative technique could abolish these

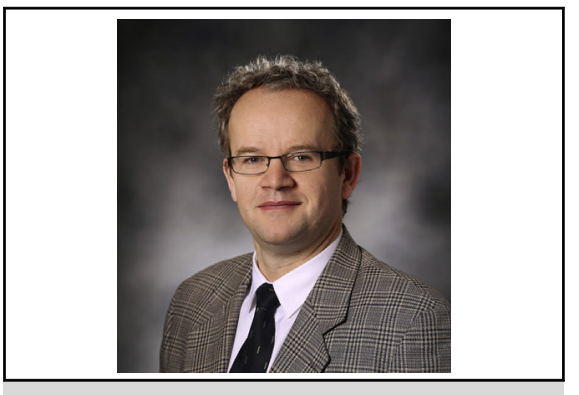

Tomasz A. Timek, MD, PhD

Central Message

Device-based assessment of leaflet coaptation forces after mitral valvuloplasty may optimize quality of valve repair.

See Article page e181.

mechanisms. In its totality, closure of the repaired mitral valve is a far departure from its normal physiologic state, and an attempt to "normalize" coaptation forces may not yield the desired result. Although clinical studies have correlated coaptation length with good distant outcomes, the gap between coaptation length and coaptation force still needs to be bridged. Apposition force of the leaflets reflects the sum of the geometric and dynamic alterations induced by valve repair and altered hemodynamic milieu related to corrected valvular insufficiency, yet its relationship to coaptation length or durability of valvular repair remains to be defined. Grinberg and colleagues ${ }^{5}$ introduce an ex vivo model to assess performance of the device. This represents an appropriate starting point, but in vivo testing in normal and repaired valves will bear more useful data. The novel technology may not represent a litmus test for adequacy of mitral repair, but it should for the first time permit assessment of mitral valve coaptation forces with various reparative techniques and hemodynamic conditions. Such data will be of considerable value in potentially identifying leaflet stress distribution, rather than physical coaptation length, as the ultimate guide to repair durability. Because the device measurements are taken after weaning from cardiopulmonary bypass, I suspect that considerable experience needs to accumulate before surgeons undertake intraoperative rerepair on account of suboptimal coaptation force distribution in the setting of a competent valve. It is feasible that the presented technologic aid may hold promise of increasing the rate of mitral valvuloplasty and provide standardized repair results beyond the realm of the mitral 
Jedi; for now, however, the ink pen may be mightier than the light saber.

\section{References}

1. Hill JD, John H, Gibbon Jr. Part I. The development of the first successful heartlung machine. Ann Thorac Surg. 1982;34:337-41.

2. Leon MB, Smith CR, Mack M, Miller DC, Moses JW, Svensson LG, et al; PARTNER Trial Investigators. Transcatheter aortic-valve implantation for aortic stenosis in patients who cannot undergo surgery. N Engl J Med. 2010;363:1597-607.

3. Bisignani A, De Bonis S, Mancuso L, Ceravolo G, Bisignani G. Implantable loop recorder in clinical practice. J Arrhythm. 2019;35:25-32.

4. Hyler S, Espinoza A, Skulstad H, Fosse E, Halvorsen PS. Left ventricular function can be continuously monitored with an epicardially attached accelerometer sensor. Eur J Cardiothorac Surg. 2014;46:313-20. Erratum in: Eur J Cardiothorac Surg. 2018;54:968.

5. Grinberg D, Bruhat A, Cottinet PJ, Le MQ, Adams DH, Costa A. Mitral valve repair based on physical characterization of coaptation forces. J Thorac Cardiovasc Surg. 2020;159:e181-3.
6. Timek T, Dagum P, Lai DT, Green GR, Glasson JR, Daughters GT, et al. The role of atrial contraction in mitral valve closure. J Heart Valve Dis. 2001;10: $312-9$

7. Glasson JR, Green GR, Nistal JF, Dagum P, Komeda M, Daughters GT, et al Mitral annular size and shape in sheep with annuloplasty rings. J Thorac Cardiovasc Surg. 1999;117:302-9.

8. Green GR, Dagum P, Glasson JR, Nistal JF, Daughters GT II, Ingels NB Jr, et al. Restricted posterior leaflet motion after mitral ring annuloplasty. Ann Thorac Surg. 1999;68:2100-6.

9. Bothe W, Rausch MK, Kvitting JP, Echtner DK, Walther M, Ingels NB Jr, et al. How do annuloplasty rings affect mitral annular strains in the normal beating ovine heart? Circulation. 2012;126(11 Suppl 1):S231-8

10. Bothe W, Kvitting JP, Swanson JC, Hartnett S, Ingels NB Jr, Miller DC. Effects of different annuloplasty rings on anterior mitral leaflet dimensions. J Thorac Cardiovasc Surg. 2010;139:1114-22.

11. Swanson JC, Krishnamurthy G, Itoh A, Kvitting JP, Bothe W, Craig Miller D, et al. Multiple mitral leaflet contractile systems in the beating heart. J Biomech. 2010;44:1328-33. 